DOI https://doi.org/10.30525/978-9934-26-040-7-28

\title{
ДО ПИТАННЯ КОНТРОЛЮ У СФЕРІ СОЦІАЛЬНОГО ДІАЛОГУ
}

\author{
Головань Т. Г. \\ кандидат юридичних наук, дочент, \\ доиент кафедри державно-правових дисииплін, \\ міжнародного права та права Європейського Союзу, \\ докторант кафедри ичвільно-правових дисииплін та трудового права \\ імені професора О. І. Прочевського \\ Харківського начіонального педагогічного університету \\ імені Г. С. Сковороди \\ м. Харків, Україна
}

В Україні одним із напрямів іiі розвитку є інтеграція до європейського співтовариства. Свроінтеграційна ідея є свідомим вибором українського суспільства. Однак процес інтеграції набуває ефективності за наявністю певних умов, зокрема, зміни законодавчої бази, впровадження стандартів та норм $Є С$, реалізації державної політики.

Розвиток економіки та суспільства можливі тільки за умови розширення соціальної бази для зміцнення демократичних інститутів $\mathrm{i}$ послідовного розвитку громадянського суспільства. При цьому реальним пріоритетом розвитку держави й економіки повинно бути забезпечення гідного життя громадян. Одним із шляхів забезпечення зазначених умов є запровадження в державі дієвої системи соціального діалогу.

Соціальний діалог базується на соціально-правових принципах. Це пояснюється тим, що соціальний діалог $є$ одним 3 напрямів взаємодії органів центральної виконавчої влади, органів місцевої виконавчої влади, органів місцевого самоврядування, роботодавців, працівників та профспілок з питань формування, реалізації державної соціальної та економічної політики, регулювання трудових, соціальних, економічних відносин у сучасній соціальній державі. Побудова ефективної системи соціального діалогу можлива лише за умови реалізації юридичних гарантій, які охороняють права та інтереси його сторін. Однією із таких юридичних гарантій є контроль у сфері соціального діалогу.

Контроль являє собою самостійну й одночасно функціонально специфічну функцію діяльності держави. Відтак, контроль - це сукупність дій, спрямованих на спостереження за функціонуванням 
відповідного об'єкта контролю 3 метою отримання об'єктивної та достовірної інформації про стан справ на ньому; вжиття заходів щодо запобігання правопорушенням; надання допомоги підконтрольній структурі в поновленні законності і дисципліни; встановлення причин та умов, що сприяють порушенню вимог правових норм; вжиття заходів для притягнення до правової відповідальності винних осіб.

В сучасній державі існує два основні види контролю, які дозволяють максимально охопити сферу соціального діалогу: державний та недержавний. Державний контроль включає контрольні дії всіх без винятку державних структур. Недержавний контроль здійснюється недержавними структурами, громадянами. Зазначена класифікація не закріплена на законодавчому рівні, однак випливає зі змісту норм Закону України «Про соціальний діалог в Україні».

Законом України «Про соціальний діалог в Україні» встановлено, що контроль за виконанням прийнятих рішень та досягнутих домовленостей здійснюється безпосередньо сторонами соціального діалогу. Особи, винні в порушенні законодавства про соціальний діалог, несуть відповідальність згідно із законом [1, ст. 19]. Такий вид контролю називають соціально-партнерським і він $є$ притаманним лише для трудового права. В теорії такий контроль поділяють за часом проведення на попередній, поточний та наступний [2, с. 53]. Попередній контроль, відповідно до Закону України «Про соціальний діалог в Україні», здійснюється НТСЕР шляхом виконання своїх основних завдань [1, п.п. 1, 2 ч. 1 ст. 12] та галузевою (міжгалузевою) радою [1, ч.ч. 1-6 ст. 16]. Поточний та наступний контроль за виконанням своїх домовленостей здійснюється сторонами соціального діалогу [1]. Однак, не зважаючи на намагання законодавця врегулювати питання контролю в сфері соціального діалогу, він не є ефективним, адже, по-перше, нормативно-правове регулювання $\epsilon$ недостатнім, по-друге, в межах його реалізації не передбачена можливість вжиття заходів юридичної відповідальності. Також не передбачений обов'язок відповідних органів у сфері соціального діалогу здійснювати контроль за виконанням, покладених на сторони соціального діалогу, обов'язків та притягувати до відповідальності за їх невиконання. Саме тому, контроль, покладений на сторони, не є дієвим. Відтак, доцільно було б передбачити державний контроль в межах всіх форм здійснення соціального діалогу.

Досить актуальним залишається питання щодо обсягу та змісту контрольних повноважень в сфері соціального діалогу, а також принципів їх реалізації. Враховуючи мету та завдання контролю в сфері 
соціального діалогу, можна виділити такі принципи контролю, як об'єктивність, дієвість, гласність, систематичність та ефективність.

Об'єктивність контролю дає змогу реально оцінити ситуацію, що склалася у сфері соціального діалогу, зіставити іiі із завданнями i визначити потребу втручання з боку відповідних державних органів. Принцип об'єктивності контролю передбачає аналіз реальних фактів та всебічність їх розгляду.

Дієвість контролю полягає в реальних наслідках виявлення порушення чинного законодавства, прийнятих норм і правил. Мета контролю полягає не лише у виявленні допущених порушень, але й у проведенні їх аналізу з метою виявлення можливих наслідків. Даний принцип покладений в основу реагування органів контролю, усієї системи контролю шляхом вжиття відповідних заходів.

Принцип гласності в діяльності органів контролю посідає важливе місце і передбачає постійний зв'язок контрольних органів з громадськістю та засобами масової інформації. Контроль, який грунтується на інформуванні громадськості про випадки правопорушень у сфері соціального діалогу сприятиме оперативному усуненню порушень та наявних недоліків. Принцип гласності контролю передбачає не лише виявлення недоліків та обов'язкове покарання, а й постановку актуальних проблем, підготовку громадської думки.

Принцип систематичності контролю в сфері соціального діалогу передбачає його регулярність. Систематичний контроль дає можливість постійно аналізувати ситуацію в сфері соціального діалогу, а також виявляти недоліки, відшукувати резерви чи попереджувати непередбачені наслідки.

Принцип ефективності контролю полягає в застосуванні найпростіших засобів контролю для досягнення високого результату та оперативність, вчасність, проведення контрольних дій. Прояв принципу ефективності, можна спостерігати у своєчасності і повноті виявлення відхилень, їх причин і винних, а також оперативності у виправленні допущених негативних результатів. Однак говорити про ефективність контролю можна лише після проведення специфічних заходів, зокрема аналізу співвідношення результату контролю та витрачених ресурсів.

В цілому реалізація принципів контролю стимулює контрольну діяльність до підвищення ефективності та позитивного впливу на досягнення результату. Аналіз принципів контролю та сутності діяльності НТСЕР дозволяє стверджувати, що вони мають схожі риси та зміст.

В цілому належне нормативно-правове врегулювання контролю в сфері соціального діалогу в Україні має, без перебільшення, велике 
значення. Адже це забезпечить можливість досягти мети соціального діалогу і він стане дієвим інструментом розвитку соціально-трудових відносин, дозволить запобігати появі та ефективно вирішувати вже існуюче широке коло проблем у сфері праці. В подальшому «практика соціального діалогу має долати межі вирішення суто трудових відносин і конфліктів. У цьому сенсі, йдеться про перспективи наповнення державної політики ідеологією соціального партнерства, та, безумовно, практичною реалізацією положень Закону України «Про соціальний діалог в Україні» [3, с. 5].

Досягнення ефективності реалізації контролю в сфері соціального діалогу для досягнення мети соціального діалогу можливе лише за умови проведення належного наукового обгрунтування та розробки дієвої системи контролю. Саме тому актуальність подальшого дослідження контролю в сфері соціального діалогу не викликає сумнівів.

\section{Література:}

1. Про соціальний діалог в Україні: Верховна Рада України; Закон України від 23 грудня 2010 р. № 2862-VI. URL: http://zakon4.rada.gov.ua/laws/show/2862-17.

2. Лушникова М. В. Социально-партнёрский контроль в трудовом праве. Актуальні проблеми трудового права i права соціального забезпечення : тези доп. та наук. повідомл. учасн. V міжнар. наук.практ. конф. (м. Харків, 27-28 верес. 2013 р.) / за ред. В. В. Жернакова. Харків: Право, 2013. С. 52-55.

3. Горєлов Д.М., Корнієвський О.А., Опалько Ю.В., Палій Г.О. Формування соціального діалогу в сучасних умовах: світовий досвід та українська практика. - К. : НІСД, 2011. - 47 с.

4. Петроє О.М. Соціальний діалог у державному управлінні: європейський досвід та українські реалії : монографія / О. М. Петроє. К. : НАДУ, 2012. - 304 с. 